\title{
Characterization of an Inhibitor of Neuronal Plasminogen Activator Released by Heart Cells
}

\author{
Randall N. Pittman' and Paul H. Patterson ${ }^{2}$ \\ ${ }^{1}$ Department of Pharmacology, University of Pennsylvania School of Medicine, Philadelphia, Pennsylvania 19104, and \\ ¿Department of Biology, California Institute of Technology, Pasadena, California 91125
}

\begin{abstract}
A basic understanding of growth cone dynamics and developmental events involving growth cones requires an understanding of the function and regulation of molecules associated with and released by growth cones. Rat sympathetic neurons in culture release a urokinase-like plasminogen activator from their distal processes and/or growth cones (Pittman, 1985a). When sympathetic neurons are grown in cocultures with heart cells, however, plasminogen activator activity is not detected. The absence of plasminogen activator activity in cocultures of sympathetic neurons and heart cells appears to be due to the release of an inhibitor of plasminogen activator by heart cells. This inhibitor has a molecular weight of approximately $50 \mathrm{kDa}$ in the presence of SDS and apparent molecular weights of approximately 50 and $>2000 \mathrm{kDa}$ under native conditions. A significant fraction of the large-molecular-weight form of the inhibitor is converted to the smaller form following treatment with heparinase. Extremely stable complexes of 68 and $80 \mathrm{kDa}$ are formed between the heart inhibitor and the plasminogen activator, urokinase, such that the complexes withstand boiling in SDS/mercaptoethanol. The data are consistent with the formation of an $80 \mathrm{kDa}$ urokinase-inhibitor complex in the presence of heparan sulfate proteoglycan and a $68 \mathrm{kDa}$ complex in the absence of heparan sulfate proteoglycan. A highly purified preparation of the heart inhibitor produces a 2- to 3-fold increase in neurite outgrowth from sympathetic neurons. These data indicate that the activity of the plasminogen activator released by sympathetic neurons can be regulated by a normal target tissue and that this regulation may result in increased neurite outgrowth from the neurons.
\end{abstract}

Growth cones are actively involved in axonal pathfinding, neurite outgrowth, and neuron-target cell interactions (Letourneau, 1983; Goodman et al., 1984; Kater and Letourneau, 1985). Since molecules released by growth cones may play important roles in these events, a better understanding of growth cone function will be obtained once molecules released by growth cones are identified and characterized and their regulation determined. Neurons of both the peripheral and central nervous

\footnotetext{
Reccived Aug. 5, 1986; revised Mar. 13, 1987; accepted Mar. 29, 1987.

This work was supported by a Grant-In-Aid from the American Heart Association with funds contributed in part by the Pennsylvania Affiliate and by B.R.S.G. SO7-RR-05415-24 (to R.N.P.) and by grants from the NINCDS and McKnight Foundation (to P.H.P.). We wish to thank Doreen McDowell and Paulette Midgette for excellent technical assistance.

Correspondence should be addressed to Randall N. Pittman at the above address.

Copyright (C) 1987 Society for Neuroscience $0270-6474 / 87 / 092664-10 \$ 02.00 / 0$
}

systems release the serine protease plasminogen activator (PA) (Krystosek and Seeds, 1981a, 1984; Soreq and Miskin, 1983; Alvarez-Buylla and Valinsky, 1985; Pittman, 1985), a significant fraction of which is released from the distal processes and/or growth cones (Krystosek and Seeds, 1984; Pittman, 1985a). Although a definitive role for PA has not been found in the nervous system, it has been suggested that it may be involved in granule cell migration (Krystosek and Seeds, 1981a; Moonen et al., 1982; Soreq and Miskin, 1983), Schwann cell movement (Krystosek and Seeds, 1984), and Schwann cell proliferation (Kalderon, 1984). Because PA is released from growth cones (Krystosek and Seeds, 1981b, 1984; Pittman, 1985a), it may be that PA activates plasminogen in the local environment of the growth cone and the plasmin thus formcd helps the growing ncurite degrade components of the extracellular matrix through which it must grow (e.g., see Tosney and Landmesser, 1985). If PA is involved in events associated with neurite outgrowth, then it might be expected that once the neurite reached its appropriate target that a decrease in PA activity would occur.

Proteases are regulated by specific activators and inhibitors. A balance between proleolytic and inhibitory activities may be an important factor in various cellular events, including neuronal development. An inhibitor of serine proteases (including PA) has recently been purified from glioma conditioned medium and has been shown to increase process outgrowth from neuroblastoma cells (Guenther et al., 1985; Monard, 1985). Several other cell types appear to release inhibitors of serine proteases (Eaton and Baker, 1983; Van Mourik et al., 1984), and although specific physiological functions have not been attributed to these inhibitors, their ability to bind to the active site of serine proteases and form stable complexes would suggest that they are important regulators of cellular processes.

Sympathetic neurons release a urokinase-like PA as well as a calcium-dependent metalloprotease (Pittman, 1985a). The present study was undertaken to determine if the release of PA by sympathetic neurons was affected by culturing neurons in the presence of a target tissue, cardiac myocytes. Thesc studies indicate that little or no PA activity is present in cocultures of neurons and heart cells and that this is the result of an inhibitor of PA released by the heart cells. A preliminary account of this work has appeared (Pittman, 1984).

\section{Materials and Methods \\ Materials}

The following drugs and reagents were used: fibrinogen (Calbiochem, San Diego), CH-Sepharose and lysine-Sepharose (Pharmacia, Piscataway, NJ), octyl-Sepharose, Sephadex G-100, Sepharose 6B, p-aminobenzamidine agarose, trypsin, chymotrypsin, urokinase, thrombin, ther- 
molysin, aminopcptidase M, heparin, and heparinase (Sigma Chemical Co., St. Louis). All other chemicals were reagent grade.

Plasminogen was purified from human serum according to the method of Deutsch and Mertz (1970).

\section{Cell culture}

Neurons from sympathetic ganglia of neonatal rats were obtained by mechanical dissociation and trituration through a 20 gauge nccdlc, followed by preplating on tissue culture plastic for $2 \mathrm{hr}$ to remove nonneuronal cells. Neurons were grown on rat tail collagen in 24 well cluster dishes $\left(2 \mathrm{~cm}^{2} /\right.$ well $)$ in serum-free $\mathrm{L} 15 \mathrm{CO}_{2}$ medium as previously described (Pittman, 1985a). The medium was a modification (Wolinsky et al., 1985) of N2 medium (Bottenstein et al., 1980) and was composed of $\mathrm{L} 15 \mathrm{CO}_{2}$ medium containing stable and fresh vitamins (Hawrot and Patterson, 1979), insulin $(5 \mu \mathrm{g} / \mathrm{ml})$, transferrin $(10 \mu \mathrm{g} / \mathrm{ml})$, progesterone $(20 \mathrm{nM})$, putrescine $(100 \mu \mathrm{M})$, selenium (30 nM), and 7S NGF (250 ng/ $\mathrm{ml})$.

Cultures of heart cells (a mixture of fibroblasts and myocytes) were established from atria and ventricles of neonatal rats by dissociating cells in $0.5 \%$ dispase (Boehringer Mannheim, Indianapolis) and $0.1 \%$ collagenase (Worthington, Malvern, PA) in calcium- and magnesiumfree Hank's buffered saline. Cultures werc grown for $1-3 \mathrm{~d}$ in $\mathrm{L} 15 \mathrm{CO}_{2}$ medium containing stable and fresh vitamins (Hawrot and Patterson, 1979) and $10 \%$ fetal calf serum. The cells were then switched to the same serum-free medium used for neurons with the exception that NGF was omitted and $200 \mathrm{ng} / \mathrm{ml} \mathrm{EGF}$ included. Highly enriched cultures of cardiac fibroblasts and myocytes were obtained by modifications of established procedures (Mohamed et al., 1983). Cells were dissociated and preplated for $1 \mathrm{hr}$ on tissue culture plastic, followed by a second preplating on tissue culture plastic for $2 \mathrm{hr}$. Nonadherent cells from the second preplating were plated on tissue culture plastic. These cells were highly enriched in cardiac myocytes ( $>80 \%$ of the cells beat spontaneously after $2-3 \mathrm{~d}$ in culture). The cells that attached during the first preplating were highly enriched in fibroblast- like cells, while the cells that attached during the second preplating were a mixture of fibroblastlike cells and myocytes. The cultures enriched in myocytes and fibroblasts were grown in serum-free medium for the duration of the experiments.

Cocultures of sympathetic neurons and heart cells were established by plating mechanically dissociated neurons on monolayers of myocytes, fibroblasts, or mixed cultures of heart cells in serum-free medium.

\section{Gel electrophoresis assays for the $P A$ inhibitor}

Inhibition method. Serum-free heart cell conditioned medium (CM) was mixed with SDS (2\% final concentration) and electrophoresed in SDS slab gels containing $7.3 \%$ acrylamide, $0.31 \%$ bisacrylamide, $0.11 \%$ gelatin, and $0.25 \mathrm{mg}$ plasminogen. Electrophoresis was at a constant current of $9 \mathrm{~mA}$ at $4^{\circ} \mathrm{C}$ in an SDS buffer (Lacmmli, 1970). SDS was removed following electrophoresis by washing the gel 3 times with 15 vol of $2 \%$ Triton X-100 (20-30 min each) while shaking at room temperature (RT). The gel was placed in $20 \mathrm{~mm}$ Tris, $\mathrm{pH} 7.5$, containing 2 units $/ \mathrm{ml}$ urokinase (UK) for $30 \mathrm{~min}$ at $\mathrm{RT}$, followed by washing 4 times with buffer without UK and incubation for $12 \mathrm{hr}$ at $30^{\circ} \mathrm{C}$. Exposure of the gel to exogenously added UK resulted in the conversion of the plasminogen in the gel to plasmin, which in turn degraded the gelatin in the gel. Inhibitors of UK block the activation of plasminogen by UK in local areas of the gel and are visualized as bands of dark blue gelatin in a clear gel following protein staining with $0.1 \%$ amido black. Inhibitors of either IIK or plasmin would be detected using this assay.

Complex formation with ${ }^{125}$ I-UK. Commercially available UK (Sigma Chemical Co.) was purified using a $p$-aminobenzamidine affinity column (Wun et al., 1982) to $>99.9 \%$ purity (determined following SDS gel electrophoresis and silver staining) and iodinated with $\mathrm{Na}^{125} \mathrm{I}$ using 1,3,4,6-tetrachloro-3a,6a-diphenylglycouril (iodogen). Iodinated protein was separated from free iodine with a Sephadex G-25 column and stored at $-70^{\circ} \mathrm{C}$ for up to 3 weeks. Serum-free $\mathrm{CM}$ from heart cells, intact heart cells, or membranes prepared from heart cells were incubated with ${ }^{123} \mathrm{I}-\mathrm{UK}$ for $30-60 \mathrm{~min}$ at 30 or $37^{\circ} \mathrm{C}$ in complete serumfree medium or $20 \mathrm{~mm}$ Tris- $\mathrm{HCl}, \mathrm{pH} 7.5$. Samples were then boiled in sample buffer containing 4\% mercaptoethanol and 2\% SDS for $5 \mathrm{~min}$ followed by SDS slab gel electrophoresis. Radiolabeled proteins were detected by autoradiography, and quantification was performed by cut-
Table 1. Effect of heart cells on neuronal PA

\begin{tabular}{ll} 
Condition & $\begin{array}{l}\text { PA activity } \\
\text { (mU/hr) }\end{array}$ \\
\hline Neuron alone culture $^{a}$ & $0.81+0.13$ \\
Heart alone culture $^{b}$ & $0.03 \pm 0.03$ \\
Neuron + heart coculture $^{a . b}$ & $0.04 \pm 0.03$ \\
Neuron CM + heart CM & $0.01 \pm 0.01$
\end{tabular}

Data are means \pm SD for duplicate cultures from 3 different platings and represent the amount of PA activity released by sympathetic neurons and heart cells into the culture medium during a $24 \mathrm{hr}$ period. The same culture medium used to determine activity in cultures of neuron alone and heart cell alone was also mixed together and incubated for $45 \mathrm{~min}$ at $30^{\circ} \mathrm{C}$ prior to determining PA activity (neuron $\mathrm{CM}+$ heart CM group).

${ }^{a}$ Expressed per 5000 neurons plated.

${ }^{b}$ Confluent $2 \mathrm{~cm}^{2}$ culture of heart cells.

ting bands out of gels and determining radioactivity using a gamma counter.

Blotting. Samples were prepared by adding SDS ( $2 \%$ final concentration) to serum-free CM from cells. Samples were run in 10 or $12 \%$ acrylamide gels at $4^{\circ} \mathrm{C}$ and $12 \mathrm{~mA}$ using a Laemmli buffer system (Laemmli, 1970). Following electrophoresis, SDS was removed from the gel by incubating in $2 \%$ Triton X-100 for $1 \mathrm{hr}$ at RT, followed by washing 4-5 times in buffer ( $10 \mathrm{~mm}$ Tris/ $77 \mathrm{~mm}$ glycine, pH 8.3). Proteins were electrophoretically transferred onto $0.45 \mu \mathrm{m}$ nitrocellulose sheets in ice-cold buffer (no methanol present) at $95 \mathrm{~V}$ for 40 min using a Trans-Blot system (Bio-Rad, Richmond, CA). Nitrocellulose strips were incubated at RT for $1 \mathrm{hr}$ in $20 \mathrm{~mm}$ Tris, $150 \mathrm{~mm} \mathrm{NaCl}, 4 \mathrm{~mm}$ EDTA, $0.1 \%$ Tween-20, pH 7.4, to block nonspecific binding, followed by incubation for $6 \mathrm{hr}$ at RT in buffer containing $0.02 \%$ Tween-20 and $5 \times 10^{5} \mathrm{cpm} / \mathrm{ml}{ }^{125}$ I-UK. The nitrocellulose was then washed $4-5$ times over a period of $1 \mathrm{hr}$ in buffer containing $0.02 \%$ Tween-20, followed by air drying and autoradiography.

\section{Assay for PA activity}

Plasminogen activator activity was quantitated using a modification of the method of Unkeless et al. (1973), as previously described (Pittman, 1985a). In short, $20 \mu \mathrm{g}$ fibrinogen $\left(10^{5} \mathrm{cpm}\right)$ was added to each well of a 24 well dish $\left(2 \mathrm{~cm}^{2} /\right.$ well $)$ and dried under vacuum. The fibrinogen was converted to fibrin using thrombin, and assays were run at $37^{\circ} \mathrm{C}$ in $0.5 \mathrm{ml}$ of $0.1 \mathrm{M}$ Tris- $\mathrm{HCl}, \mathrm{pH} 8.1$, containing $0.1 \%$ gelatin, $2 \mu \mathrm{g}$ human plasminogen, and 5-250 $\mu \mathrm{l}$ serum-free conditioned medium. Aliquots were removed, and radioactivity was determined after 1,2 , and $3 \mathrm{hr}$.

\section{Column chromatography}

IIeparin-sepharose. CH-Sepharose 4B (1 gm) was swollen for 45 min in ice-cold $1 \mathrm{~mm} \mathrm{HCl}$ followed by washing with $200 \mathrm{ml}$ ice-cold $1 \mathrm{~mm}$ $\mathrm{HCl}$. Grade II heparin, $0.7 \mathrm{gm}$ (Sigma), was dissolved in $12 \mathrm{ml}$ of 0.1 $\mathrm{M}$ bicarbonate buffer containing $0.5 \mathrm{M} \mathrm{NaCl}, \mathrm{pH} 8.2$, and added to the $\mathrm{CH}$-Sepharose. The mixture was shaken for $2 \mathrm{hr}$ at $22^{\circ} \mathrm{C}$ and then for $14 \mathrm{hr}$ at $4^{\circ} \mathrm{C}$. Excess reactive groups on the resin were blocked by incubating with $50 \mathrm{~mm}$ Tris, $0.5 \mathrm{M} \mathrm{NaCl}, \mathrm{pH} 8.0$, for $2 \mathrm{hr}$.

Samples of serum-free heart CM (2-200 ml) were loaded onto the heparin-Sepharose column $(0.6 \times 4.5 \mathrm{~cm}$ column bed $)$ with a flow rate of $1 \mathrm{ml} / \mathrm{min}$. The vast majority of proteins passed through the column, including the form of the inhibitor that formed an $80 \mathrm{kDa}$ complex with ${ }^{125}$ I-UK. In a typical experiment, the column was then washed with 20 $\mathrm{ml}$ of $50 \mathrm{~mm}$ Tris, $\mathrm{pH} 7.5$, and then with $20 \mathrm{ml}$ of $0.1 \mathrm{M} \mathrm{NaCl}$ in 50 mu Tris, $20 \mathrm{ml}$ of $0.3 \mathrm{M} \mathrm{NaCl}$ in $50 \mathrm{~mm}$ Tris, $5 \mathrm{ml}$ of $0.7 \mathrm{M} \mathrm{NaCl}$ in $50 \mathrm{~mm}$ Tris, and $5 \mathrm{ml}$ of $1.0 \mathrm{M} \mathrm{NaCl}$ in $50 \mathrm{~mm}$ Tris. Most of the inhibitor that formed the $68 \mathrm{kDa}$ complex with ${ }^{125} \mathrm{I}$-UK was eluted at $0.7 \mathrm{M} \mathrm{NaCl}$ and a small amount at $1.0 \mathrm{M} \mathrm{NaCl}$.

For purification of the inhibitor, the fractions eluted from the heparinSepharose column with 0.7 and $1.0 \mathrm{M} \mathrm{NaCl}$ were adjusted to $0.5 \mathrm{M}$ $\mathrm{NaCl}$ and reapplied to the heparin-Sepharose column equilibrated with $0.5 \mathrm{M} \mathrm{NaCl}$. The column was washed with 3 column volumes of $0.5 \mathrm{M}$ $\mathrm{NaCl}$ and the inhibitor was eluted from the column with $0.8 \mathrm{M} \mathrm{NaCl}$.

Gel filtration. Serum-free CM from heart cell cultures containing both fibroblasts and myocytes was concentrated 15-fold using an Amicon concentrator and loaded along with molecular-weight standards (amy- 


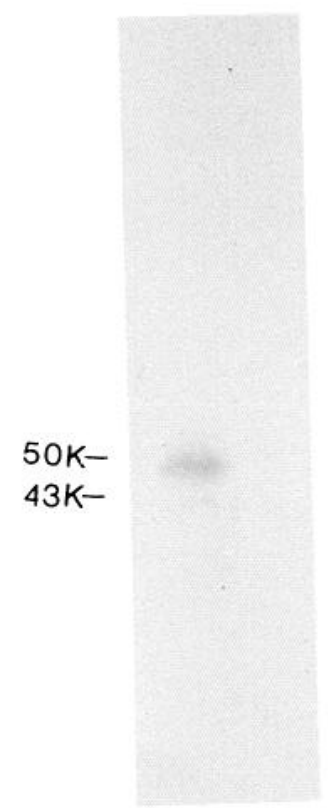

Figure 1. Inhibitors of PA released by cultures of heart cells. Serumfree CM from heart cell cultures was electrophoresed in a polyacrylamide gel in which plasminogen and gelatin had been cross-linked. Following removal of SDS, the gel was exposed to the PA, urokinase (UK), which activated the plasminogen to form plasmin. The plasmin degraded all gelatin incorporated in the gel except where inhibitors of PA (or plasmin) were present. The presence of inhibitors was detected as bands of gelatin remaining in a clear gel following staining for protein with amido black. The quantity of protein present in serum-free medium was not sufficient to be detected following staining with amido black. The bands at 50 and $43 \mathrm{kDa}$ represent bands of gelatin that were not degraded by urokinase-activated plasmin.

lase, $200 \mathrm{kDa}$; BSA, $66 \mathrm{kDa}$; carbonic anhydrase, $29 \mathrm{kDa}$ ) in a total volume of $0.25 \mathrm{ml}$ on an $0.7 \times 60 \mathrm{~cm}$ column of Sephadex G-100 previously equilibrated with PBS. The column was eluted with PBS at a rate of $0.5 \mathrm{ml} / \mathrm{min}$, and $0.1 \mathrm{ml}$ samples were collected. Samples were reacted for $60 \mathrm{~min}$ at $30^{\circ} \mathrm{C}$ with $10^{5} \mathrm{cpm}^{125} \mathrm{I}-\mathrm{UK}$ prepared for SDS gel electrophoresis and autoradiography as described above.

Serum-free heart CM was concentrated 20 -fold, and $0.5 \mathrm{ml}$ was loaded along with molecular-weight standards (blue dextran, $2000 \mathrm{kDa}$; thyroglobulin, $670 \mathrm{kDa}$; amylase, $200 \mathrm{kDa}$; BSA, $66 \mathrm{kDa}$; carbonic anhydrase, $29 \mathrm{kDa}$ ) onto a $0.8 \times 75 \mathrm{~cm}$ Sepharose $6 \mathrm{~B}$ column previously equilibrated with PBS. The column was eluted with PBS at a rate of 0.4 $\mathrm{ml} / \mathrm{min}$, and $0.95 \mathrm{ml}$ fractions were collected and reacted with $4 \times 10^{5}$ $\mathrm{cpm}$ of ${ }^{125} \mathrm{I}-\mathrm{UK}$ for $60 \mathrm{~min}$. Samples were then processed for SDS gel electrophoresis and autoradiography as described above.

Octyl-Sepharose. The fraction eluted from a heparin affinity column containing the inhibitor (eluted at $0.7 \mathrm{M} \mathrm{NaCl}$ ) was dialyzed against 10 $\mathrm{mm}$ phosphate buffer, $\mathrm{pH} 7.4$, and brought to $1.2 \mathrm{M}$ ammonium sulfate and $0.1 \mathrm{mg} / \mathrm{ml} \mathrm{BSA}$. Samples $(2-10 \mathrm{ml})$ were loaded onto an octylSepharose column ( $1 \mathrm{ml}$ bed volume) previously equilibrated with 1.2 $\mathrm{M}$ ammonium sulfate in $10 \mathrm{~mm}$ phosphate buffer, $\mathrm{pH}$ 7.4. Protein was eluted with a decreasing linear gradient of ammonium sulfate, followed by an increasing linear gradient of Triton X-100 to a maximum of 3\% Triton X-100 in water. Samples were diluted to $0.2 \mathrm{M}$ ammonium sulfate or $0.2 \%$ Triton X-100 prior to reacting with ${ }^{125} \mathrm{I}-\mathrm{UK}$, electrophoresis, and autoradiography. Neither of these concentrations of reagents affected the binding of ${ }^{125} \mathrm{I}$-UK to the inhibitor.

\section{Heparinase treatment of heart $C M$}

Serum-free heart CM (20-fold concentrated) was incubated with 280 $\mu \mathrm{g} / \mathrm{ml}$ heparinase (catalog no. H 7505 , Sigma) containing also $\sim 2 \%$ heparitinase and $1 \%$ hyaluronidase activity (see Yang et al., 1985, for specificity of heparinase) for $2.5 \mathrm{hr}$ at $32^{\circ} \mathrm{C}$. The sample was then loaded onto a Sepharose 6B column with appropriate molecular-weight standards and chromatography performed as described above.

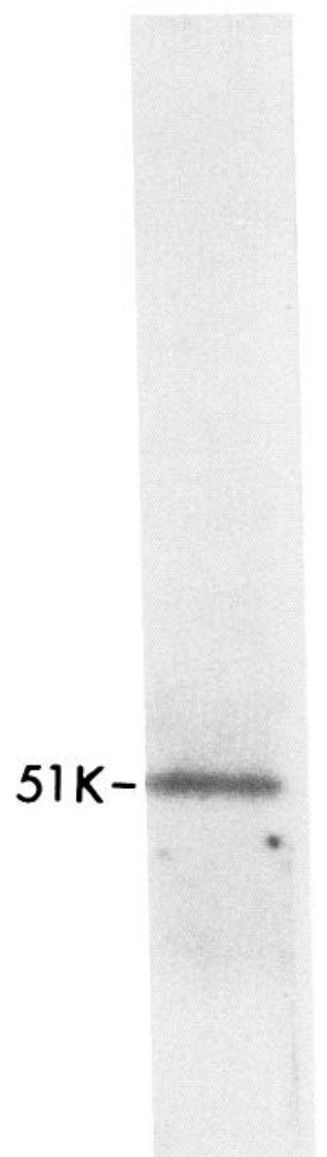

Figure 2. Protein released by heart cells that binds PA. Serum-free $\mathrm{CM}$ from heart cell cultures was electrophoresed in a polyacrylamide gel and blotted onto nitrocellulose. The nitrocellulose was then probed with ${ }^{125}$ I-UK followed by autoradiography. The band at $51 \mathrm{kDa}$ represents a protein released by heart cells that binds ${ }^{125} I-U K$.

\section{Neurite outgrowth studies}

Sympathetic neurons were plated onto Type I collagen at low density $\left(50-100\right.$ cells $\left./ \mathrm{cm}^{2}\right)$ in $35 \mathrm{~mm}$ tissue culture dishes in serum-free L-15 medium (see Cell culture). Neurons were grown for $18 \mathrm{hr}$ in the absence or presence of a highly purified fraction of the heart inhibitor and then fixed with PBS containing $2 \%$ glutaraldehyde. Morphometric data were obtained on neurite outgrowth parameters using a computer-based videomicroscopy system consisting of an IBM XT computer, Dage Newvicon video camera, Panasonic monitor, and Houston Hi-Pad. Neurite outgrowth parameters were obtained only from isolated neurons that did not contract other neurons or non-neuronal cells.

\section{Results}

\section{$P A$ activity in cocultures of sympathetic neurons and heart} cells

To determine the effects of a normal target tissue on neuronal PA activity, sympathetic neurons were grown in the presence of heart cells, and the amount of PA released into the culture medium was determined. Neurons cultured in the absence of heart cells released considerable PA, whereas little or no PA activity was detected in cocultures of heart cells and sympathetic neurons (Table 1). A number of possibilities could explain this observation, including regulation of PA release by the target tissue or the release of an inhibitor of PA by heart cells. To investigate the second possibility, CM from neuron alone cultures (containing PA) was mixed with CM from heart cell cultures (source of potential inhibitor). This "mixing" experiment 


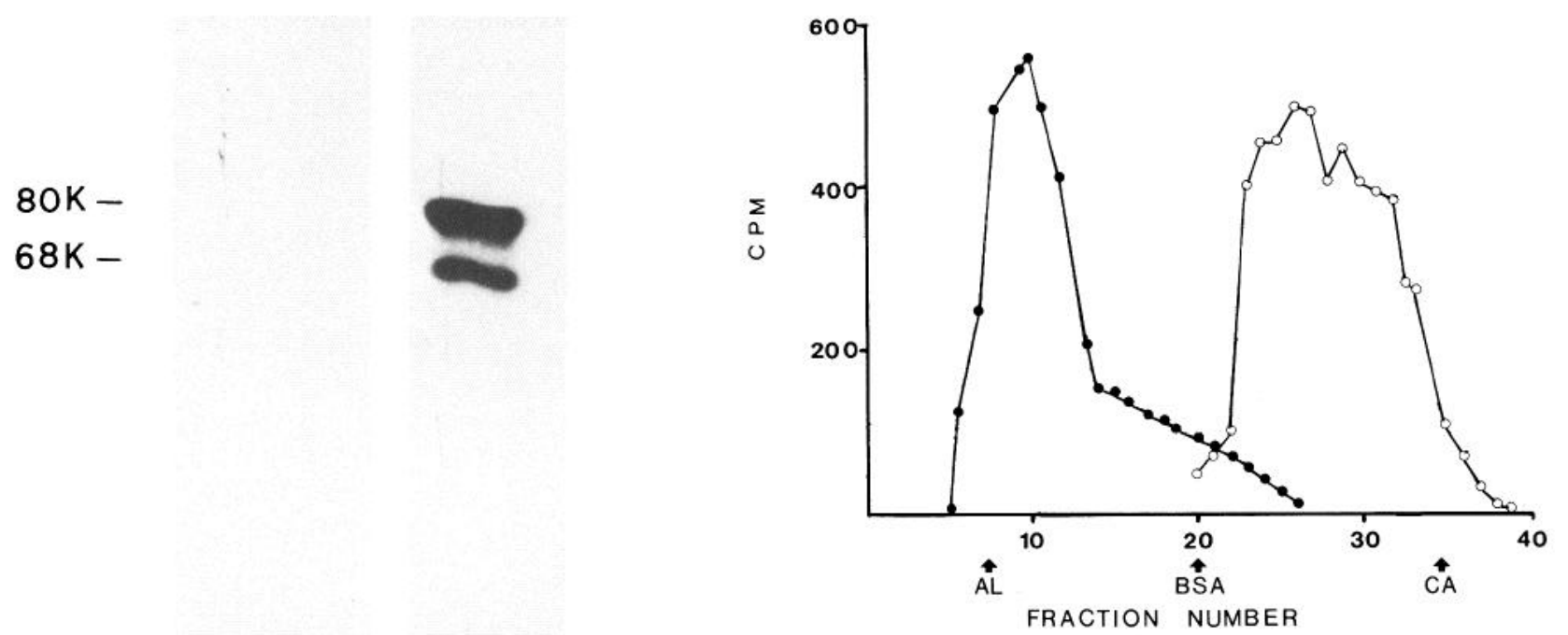

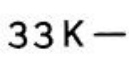

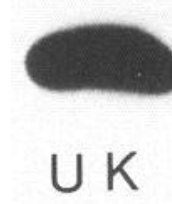

C M

Figure 3. Complexes between ${ }^{125} \mathrm{I}-\mathrm{UK}$ and proteins in serum-free heart CM. ${ }^{125}$ I-UK was mixed with serum-free L15 medium (lane 1, UK) or with serum-free CM from heart cell cultures (lane 2, CM) for $45 \mathrm{~min}$ at $30^{\circ} \mathrm{C}$ followed by boiling in SDS, electrophoresis, and autoradiography.

indicated that the neuronal PA had little or no activity following incubation with heart cell CM (Table 1). This finding suggested that an inhibitor of PA that inactivated the neuronal PA was being released by heart cells.

\section{Inhibitor released by cultures of heart cells}

A more direct assay for the presence of potential inhibitors in heart cell CM was developed (see Materials and Methods, Inhibition method). In short, CM from heart cells was electrophoresed in a polyacrylamide gel containing gelatin and plasminogen. The gel was then exposed to a solution of UK (the neuronal PA is a UK-like PA: Pittman, 1985a); this activated the plasminogen incorporated in the gel to form plasmin, which degraded the gelatin. Inhibitors (of either UK or plasmin) block the degradation of gelatin in specific areas of the gel and are detected as bands of gelatin in a clear gel. Using this assay, a major band of gelatin was present at $50 \mathrm{kDa}$ and a minor band at $43 \mathrm{kDa}$ (Fig. 1).

The possibility that additional molecules were released from heart cells that bound PA but did not inhibit its activity was investigated. Proteins released by heart cells were electrophoresed, transferred to nitrocellulose, and "probed" with ${ }^{125} \mathrm{I}-\mathrm{UK}$. Using this procedure a single protein with a molecular weight of $51 \mathrm{kDa}$ was consistently found to bind ${ }^{125} \mathrm{I}-\mathrm{UK}$ (Fig. 2). This $51 \mathrm{kDa}$ protein probably represents the $50 \mathrm{kDa}$ inhibitor described above.

\section{Complex formation between PA and heart proteins}

The above data indicated that heart cells were releasing at least one or possibly 2 proteins that bound PA and inhibited its
Figure 4. Separation of heart inhibitors following gel filtration on Sephadex G-100. Serum-free CM $(0.25 \mathrm{ml})$ from heart cell cultures containing both fibroblasts and myocytes was concentrated 15 -fold and loaded onto a $0.7 \times 60 \mathrm{~cm}$ column of Sephadex G-100. The column was eluted with PBS at a rate of $0.5 \mathrm{ml} / \mathrm{min}$, and $0.1 \mathrm{ml}$ samples were collected. Samples were reacted with ${ }^{125} \mathrm{I}-\mathrm{UK}$ for $60 \mathrm{~min}$ and then processed for SDS gel electrophoresis and autoradiography. Bands corresponding to the $68 \mathrm{kDa}(0)$ and $80 \mathrm{kDa}(\bullet)$ complexes were cut out of the gels and the radioactivity detected using a gamma counter. Molecular-weight standards are denoted by bold arrows: $A L$ (amylase, 200 $\mathrm{kDa}$ ); $B S A$ (bovine serum albumin, $66 \mathrm{kDa}$ ); and $C A$ (carbonic anhydrase, $29 \mathrm{kDa})$.

activity. Knowing the approximate molecular weights of the inhibitors (50 and $43 \mathrm{kDa}$ ) and that of ${ }^{125} \mathrm{I}-\mathrm{UK}(33 \mathrm{kDa})$, it was possible to look for the complexes formed between ${ }^{125} \mathrm{I}-\mathrm{UK}$ and the inhibitors. When ${ }^{125} \mathrm{I}-\mathrm{UK}$ was mixed with heart cell CM followed by PAGE and autoradiography, less radioactivity was present in the band at $33 \mathrm{kDa}$ (125 I-UK), and 2 new bands appeared at molecular weights of 80 and $68 \mathrm{kDa}$ (Fig. 3). The complexes between ${ }^{125} \mathrm{I}-\mathrm{UK}$ and proteins released by heart cells were stable following boiling in SDS/mercaptoethanol, which indicated that extremely stable complexes were being formed between ${ }^{125} \mathrm{I}-\mathrm{UK}$ and the protein(s) released by heart cells.

\section{Properties of inhibitor(s) under native conditions}

The molecular weights of the heart inhibitor(s) following SDSPAGE were approximately 43 and $50 \mathrm{kDa}$ (Fig. 1); however, these molecular weights may not reflect the state of the inhibitor(s) under physiological conditions. To determine if these inhibitors represented subunits of larger structures or if additional molecules were associated with them under native conditions, heart cell CM was fractionated over Sephadex G-100 and Sepharose 6B. Gel filtration chromatography of heart cell CM using Sephadex G-100 indicated that the heart inhibitor protein that formed a $68 \mathrm{kDa}$ complex with ${ }^{125} \mathrm{I}-\mathrm{UK}$ migrated near $50 \mathrm{kDa}$ (Fig. 4). The heart protein that formed the $80 \mathrm{kDa}$ complex with ${ }^{125} \mathrm{I}-\mathrm{UK}$ ran at the exclusion volume of the Sephadex G-100 column, which indicated that, in the absence of SDS, this protein had an apparent $M_{r}$ of $>150 \mathrm{kDa}$. This suggested that the heart protein that formed the $80 \mathrm{kDa}$ complex with ${ }^{125} \mathrm{I}-\mathrm{UK}$ was either associated with other macromolecules or was part of a multisubunit complex that dissociated following exposure to SDS.

Fractionation of heart cell inhibitors on Sepharose $6 \mathrm{~B}$ indicated that the heart inhibitor that formed the $80 \mathrm{kDa}$ complex 


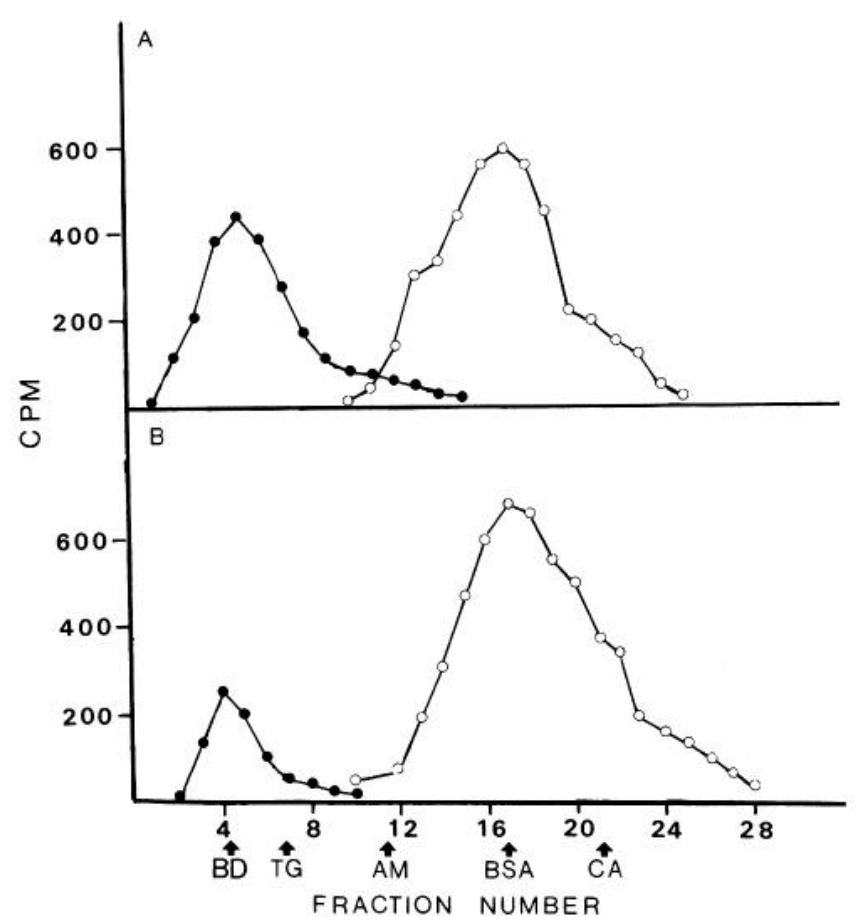

Figure 5. Separation of heart inhibitors following gel filtration on Sepharose $6 \mathrm{~B}$. Serum-free heart $\mathrm{CM}$ was concentrated 20 -fold and 0.5 $\mathrm{ml}$ either loaded onto a $0.8 \times 75 \mathrm{~cm}$ Sepharose $6 \mathrm{~B}$ column $(A)$ or incubated with $140 \mu \mathrm{g}$ heparinase for $2.5 \mathrm{hr}$ and then loaded onto a $0.8 \times 75 \mathrm{~cm}$ Sepharose 6B column $(B)$. The column was eluted with PBS at a rate of $0.4 \mathrm{ml} / \mathrm{min}$, and $0.95 \mathrm{ml}$ fractions were collected and reacted with ${ }^{125} \mathrm{I}-\mathrm{UK}$ for $60 \mathrm{~min}$ and then processed for SDS gel electrophoresis and autoradiography. Bands corresponding to the $68 \mathrm{kDa}$ $(O)$ and $80 \mathrm{kDa}(0)$ complexes were cut out of the gel and the radioactivity detected using a gamma counter. Less than $10 \%$ of the radioactivity remained in the stacking gel, indicating that the inhibitor was released from the large-molecular-weight complex in the presence of SDS. Molecular-weight standards are denoted by bold arrows: $B D$, blue dextran $(2000 \mathrm{kDa}) ; T G$, thyroglobulin $(670 \mathrm{kDa}) ; A M$, amylase $(200$ $\mathrm{kDa}) ; B S A$, bovine serum albumin $(66 \mathrm{kDa}) ; C A$, carbonic anhydrase $(29 \mathrm{kDa})$. with ${ }^{125}$ I-UK migrated ahead of dextran blue, suggesting a molecular weight of $>2 \times 10^{6} \mathrm{Da}$ (Fig. $5 \mathrm{~A}$ ). To investigate other potential components of this macromolecular complex, a sample of heart cell $\mathrm{CM}$ was treated with heparinase followed by fractionation over a Sepharose 6B column. Heparinase treatment decreased the amount of protein that migrated with a molecular weight of $>2 \times 10^{6} \mathrm{Da}$ by about $70 \%$ and increased the amount of protein that eluted with low-molecular-weight components by a comparable amount (Fig. $5 B$ ). Of particular significance was that the increase in the low-molecular-weight component following heparinase treatment resulted in an increase in the amount of the $68 \mathrm{kDa}$ complex and not in the 80 $\mathrm{kDa}$ complex. This suggested that a single inhibitor might be present that formed a $68 \mathrm{kDa}$ complex with ${ }^{125} \mathrm{I}-\mathrm{UK}$ in the absence of heparan sulfate proteoglycan and an $80 \mathrm{kDa}$ complex in its presence.

\section{Interactions of the heart inhibitor with heparin}

The experiments with heparinase suggested that under physiological conditions, the inhibitor could interact with heparin sulfate proteoglycans; therefore, the interaction of the inhibitor with heparin was investigated by fractionating heart cell $\mathrm{CM}$ on a heparin Sepharose column. The heart inhibitor that interacted with ${ }^{125} \mathrm{I}-\mathrm{UK}$ to form the $68 \mathrm{kDa}$ complex bound quantitatively with high affinity to heparin Sepharose, whereas the heart protein that formed the $80 \mathrm{kDa}$ complex did not bind to the heparin-Sepharose column (Fig. 6). Because of its association with a large macromolecular complex that probably included heparan sulfate proteoglycan, this form of the inhibitor may not have had access to the heparin bound to the Sepharose matrix.

Advantage was taken of the finding that 2 forms of the inhibitor could be quantitatively separated on a heparin Sepharose column. This allowed experiments to be performed to determine the effects of heparin on complex formation.

Heart cell CM was fractioned using heparin Sepharose into a fraction containing the inhibitor that formed the $80 \mathrm{kDa}$ com-

Figure 6. Separation of inhibitors following chromatography on heparin Sepharose. Serum-free heart CM $(50 \mathrm{ml})$ was loaded onto a $0.6 \times 4.5 \mathrm{~cm}$ heparin-Sepharose column. The column was then washed with sequential $10 \mathrm{ml}$ volumes of $50 \mathrm{~mm}$ Tris, $\mathrm{pH} 7.5$, containing $0,0.1$, or $0.3 \mathrm{M} \mathrm{NaCl}$ followed by $3 \mathrm{ml}$ of $50 \mathrm{~mm}$ Tris containing 0.7 or $1.0 \mathrm{M} \mathrm{NaCl}$. A $0.01 \mathrm{ml}$ sample of each fraction was adjusted to $0.2 \mathrm{M} \mathrm{NaCl}$ and reacted with ${ }^{125}$ I-UK, followed by electrophoresis and autoradiography. Lanes represent serum-free L15 medium $(U K)$, serum-free heart $\mathrm{CM}$ prior to chromatography $(C M)$, heart $C M$ that flowed through the heparin column (FT), protein eluted with $0.3 \mathrm{M} \mathrm{NaCl}$ $(0.3 \mathrm{M})$, and protein eluted with $0.7 \mathrm{M}$ $\mathrm{NaCl}(0.7 M)$. Note that the band at 33 $\mathrm{kDa}$ represents ${ }^{125} \mathrm{I}-\mathrm{UK}$ added to all samples, whereas the bands at 68 and $80 \mathrm{kDa}$ represent complexes between ${ }^{125} \mathrm{I}-\mathrm{UK}$ and proteins released by heart cells. No complexes were present at 0 , 0.1 , and $1.0 \mathrm{M} \mathrm{NaCl}$; therefore, these samples are not included in the figure.

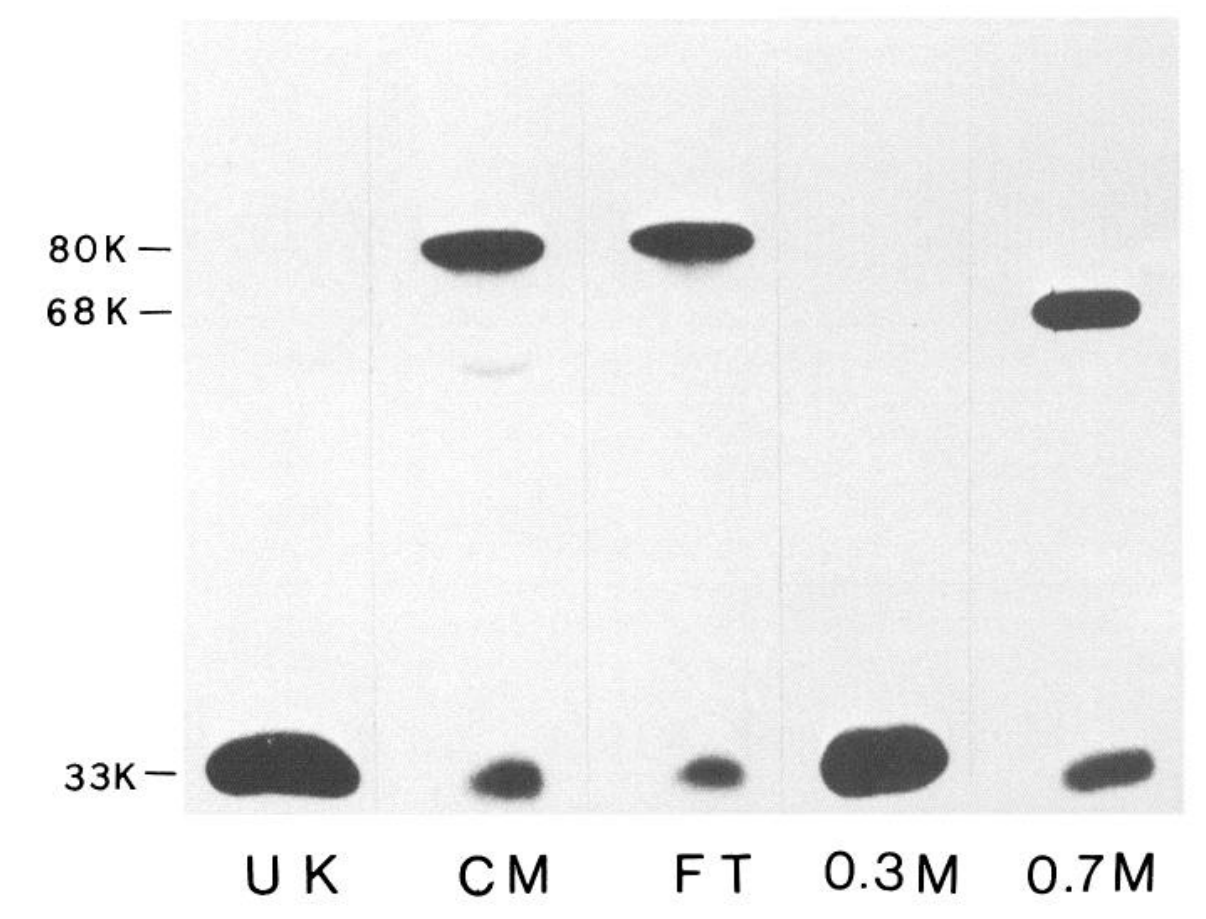



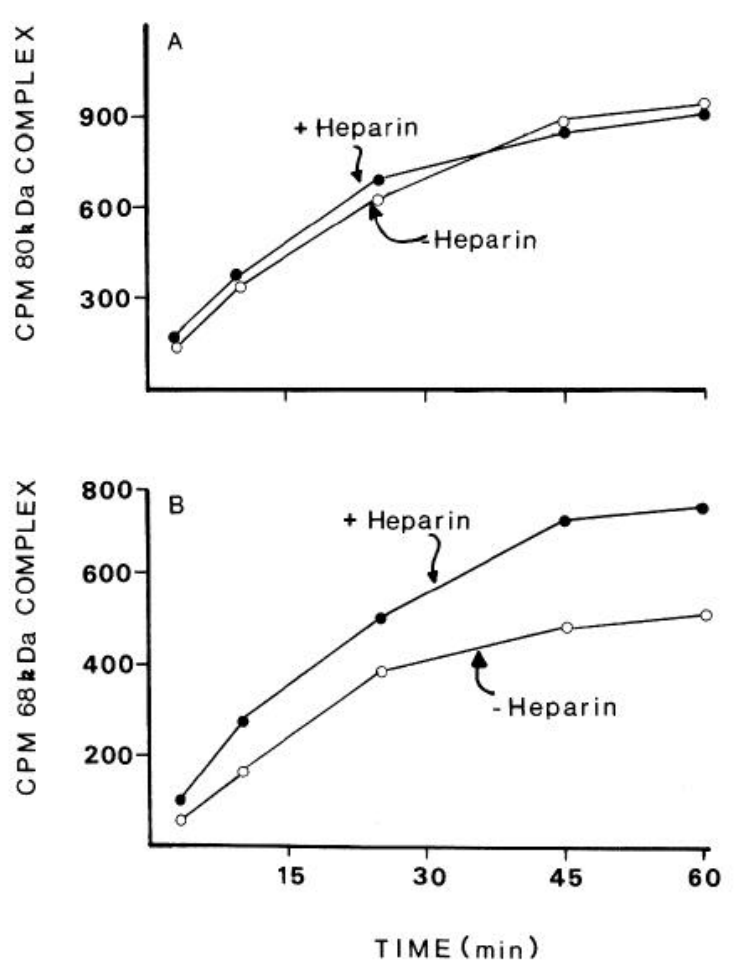

Figure 7. Effect of heparin on $80 \mathrm{kDa}(A)$ and $68 \mathrm{kDa}(B)$ proteaseinhibitor complex formation. Serum-free heart $C M$ was fractionated using heparin-Sepharose into a fraction containing the inhibitor that formed the $80 \mathrm{kDa}$ complex (the flow-through fraction) and a fraction containing the inhibitor that formed the $68 \mathrm{kDa}$ complex (the fraction eluted with $0.7 \mathrm{M} \mathrm{NaCl}$ ). Each fraction was adjusted to $0.2 \mathrm{M} \mathrm{NaCl}$ and incubated with ${ }^{125} \mathrm{I}-\mathrm{UK}$ in the absence $(O)$ or presence $(\bullet)$ of $0.5 \mathrm{mg} /$ $\mathrm{ml}$ heparin. Aliquots were removed at the indicated times, boiled in SDS/mercaptoethanol, and electrophoresed. Bands corresponding to the 68 and $80 \mathrm{kDa}$ complexes were cut from the gels and the radioactivity determined. Data represent averages of 2 experiments.

plex (the flow-through fraction) and a fraction containing the inhibitor that formed the $68 \mathrm{kDa}$ complex (eluted from the column with $0.7 \mathrm{M} \mathrm{NaCl}$ ). Each fraction was tested to determine the effect of heparin on complex formation with ${ }^{125} \mathrm{I}-\mathrm{UK}$. Heparin had no effect on the formation of the $80 \mathrm{kDa}$ complex (Fig. $7 A$ ), whereas the presence of heparin increased the amount of the $68 \mathrm{kDa}$ complex formed (Fig. $7 \mathrm{~B}$ ). In addition to increasing the amount of the $68 \mathrm{kDa}$ complex, the presence of heparin also resulted in the formation of a small amount of an $80 \mathrm{kDa}$ complex between ${ }^{125} \mathrm{I}-\mathrm{UK}$ and the inhibitor in the fraction eluted from the heparin affinity column (Fig. 8). This supports the data presented in Figure 5 and suggests that the 2 heart inhibitors are the same protein and that in the presence of heparin or heparan sulfate proteoglycan a stable $80 \mathrm{kDa}$ complex is formed with ${ }^{125} \mathrm{I}-\mathrm{UK}$. In the absence of heparin or heparan sulfate proteoglycan, a $68 \mathrm{kDa}$ complex appears to be formed. Although some $80 \mathrm{kDa}$ complex was formed when the partially purified inhibitor was incubated with ${ }^{125} \mathrm{I}-\mathrm{UK}$ in the presence of heparin, it was not a quantitative conversion from the $68 \mathrm{kDa}$ complex to the $80 \mathrm{kDa}$ complex. The reason for this is unclear, although heparan sulfate proteoglycan may stabilize the $80 \mathrm{kDa}$ complex better than heparin or other components in the large proteoglycan complex may be involved in the formation of the $80 \mathrm{kDa}$ complex.

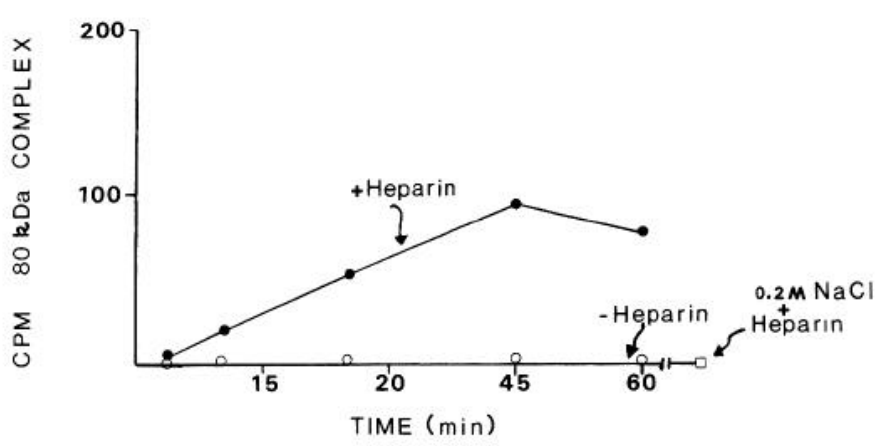

Figure 8. Formation of some $80 \mathrm{kDa}$ complex between ${ }^{125} \mathrm{I}-\mathrm{UK}$ and the inhibitor eluted from the heparin-Sepharose column. The inhibitor that bound to the heparin-Sepharose column was eluted with $0.7 \mathrm{M}$ $\mathrm{NaCl}$ and incubated with ${ }^{125} \mathrm{I}-\mathrm{UK}$ in the presence and absence of heparin as described in Figure 8. In the absence of heparin (O), no $80 \mathrm{kDa}$ complex was formed, whereas in the presence of $0.5 \mathrm{mg} / \mathrm{ml} \mathrm{heparin} \mathrm{( \bullet ),}$ some $80 \mathrm{kDa}$ complex was formed between ${ }^{125}$ I-UK and the inhibitor eluted from the heparin-Sepharose column. Heparin alone without the column fraction ( $\square$ ) did not form $80 \mathrm{kDa}$ complex with ${ }^{125} \mathrm{I}-\mathrm{UK}$. These data were taken from the same gels as data in Figure 7. Data represent averages of 2 experiments.

\section{Inhibitor associated with cardiac myocytes and fibroblasts}

Because heart cell cultures are composed of both myocytes, which are a normal target for sympathetic neurons, and fibroblasts, which are not, it was of interest to determine if the inhibitor was associated with cardiac myoctyes. Highly enriched populations of both cardiac myocytes and fibroblasts were prepared. Conditioned medium from each cell type totally inhibited neuronal PA activity (not shown), and both cell types released proteins that formed extremely stable complexes with ${ }^{125} \mathrm{I}-\mathrm{UK}$

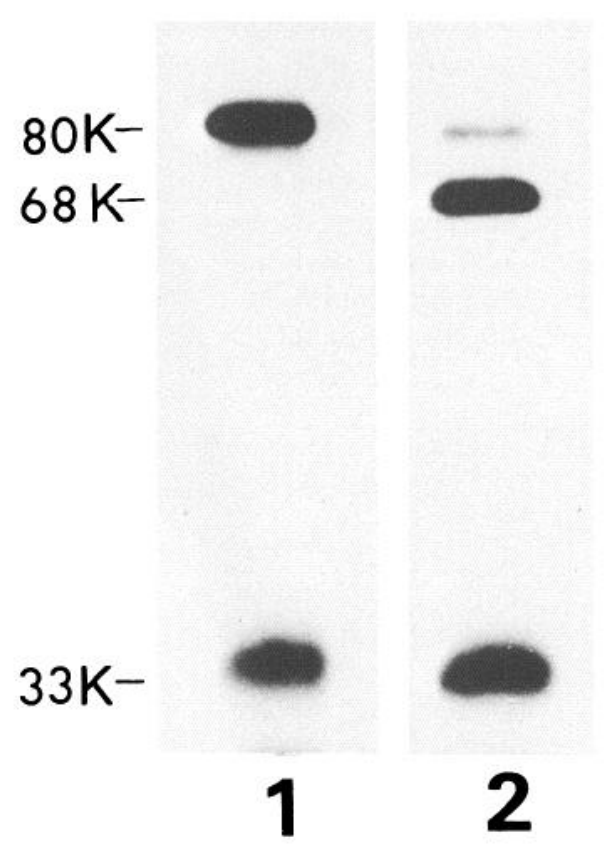

Figure 9. Complex between ${ }^{125} \mathrm{I}-\mathrm{UK}$ and proteins in serum-free medium from cardiac fibroblasts (lane 1) and cardiac myocytes (lane 2). Samples of serum-free CM from cultures containing predominantly cardiac fibroblasts or cardiac myocytes were incubated with ${ }^{125} \mathrm{I}-\mathrm{UK}$ and then processed for electrophoresis and autoradiography. Note the enrichment of the $80 \mathrm{kDa}$ complex in fibroblast $\mathrm{CM}$ and the enrichment in the $68 \mathrm{kDa}$ complex in the myocyte CM. 


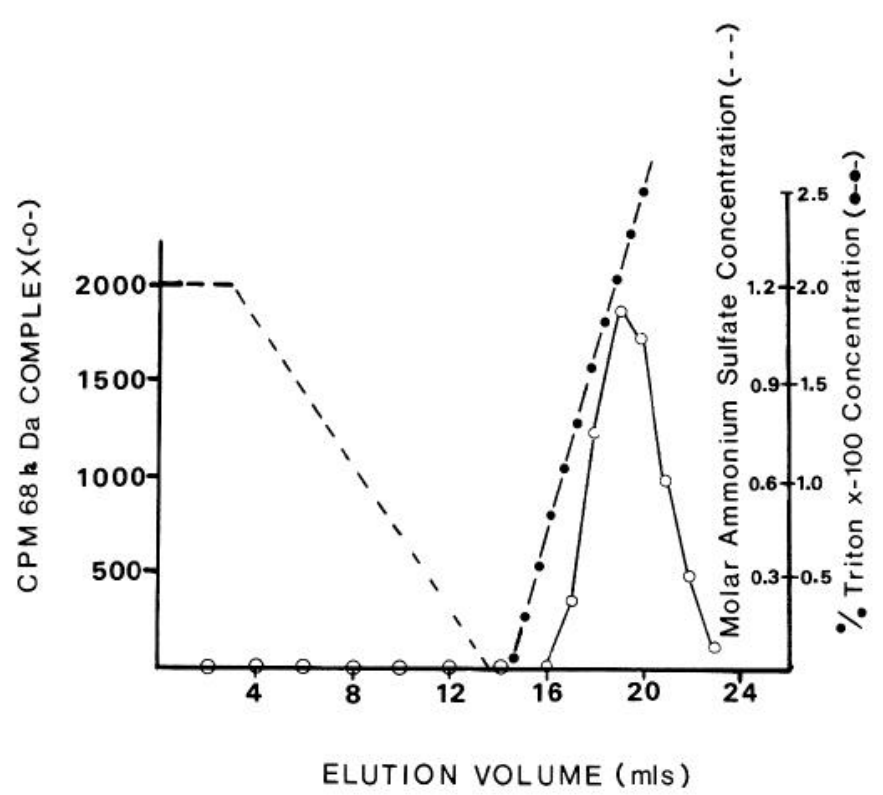

Figure 10. Elution of the inhibitor from octyl-Sepharose. The inhibitor was eluted from a heparin-Sepharose column with $0.7 \mathrm{M} \mathrm{NaCl}$, dialyzed

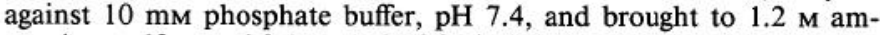
monium sulfate and $0.1 \mathrm{mg} / \mathrm{ml}$ BSA. A $4.0 \mathrm{ml}$ sample was loaded onto a $1 \mathrm{ml}$ octyl-Sepharose column equilibrated with $1.2 \mathrm{M}$ ammonium sulfate in $10 \mathrm{~mm}$ phosphate buffer, $\mathrm{pH}$ 7.4. Protein was eluted with a decreasing linear gradient of ammonium sulfate, followed by an increasing linear gradient of Triton X-100. Samples were diluted to 0.2 $\mathrm{M}$ ammonium sulfate or $0.2 \%$ Triton $\mathrm{X}-100$, reacted with ${ }^{125} \mathrm{I}-\mathrm{UK}$, and electrophoresed, and the radioactivity was determined in the $68 \mathrm{kDa}$ band.

(Fig. 9). The inhibitor from cultures enriched in fibroblasts formed an $80 \mathrm{kDa}$ complex with ${ }^{125} \mathrm{I}$-UK (Fig. 9, lane 1), whereas the inhibitor from cultures enriched in myocytes formed primarily the $68 \mathrm{kDa}$ complex (Fig. 9, lane 2).

\section{Protease selectivity of the inhibitor}

An indication of the types of proteases that bind the heart inhibitor was obtained by preincubating heart cell CM with varying concentrations of proteases, followed by incubating samples with ${ }^{125}$ I-UK (Table 2). The ability of the added proteases to block the formation of the 68 and/or $80 \mathrm{kDa}$ complexes with

\section{Table 2. Ability of proteases to block binding of ${ }^{125}$ I-UK to heart inhibitors}

\begin{tabular}{lcc} 
& $\mathrm{EC}_{50}(\mathrm{nM})$ & \\
\cline { 2 - 3 } & $\begin{array}{l}68 \mathrm{kDa} \\
\text { complex }\end{array}$ & $\begin{array}{l}80 \mathrm{kDa} \\
\text { complex }\end{array}$ \\
\hline Thetease & $>1000$ & $>1000$ \\
Aminopeptidase M & $>1000$ & $>1000$ \\
Trypsin & 7 & 6 \\
Chymotrypsin & 11 & 14 \\
Plasmin & 3 & 3 \\
Urokinase & 4 & 6 \\
Thrombin & 9 & $>1000$
\end{tabular}

Data are the average of 2 experiments. $\mathrm{EC}_{50}$ is the concentration of protease that decreased complex formation of inhibitors with ${ }^{125} \mathrm{I}-\mathrm{UK}$ by $50 \%$. Heart CM was incubated with the indicated proteases $(0.3,1,3,10,30,100,1000 \mathrm{~nm})$ for $60 \mathrm{~min}$ at $30^{\circ} \mathrm{C}$ prior to incubation with ${ }^{125} \mathrm{I}-\mathrm{UK}$ for $60 \mathrm{~min}$. Bands corresponding to the 68 and $80 \mathrm{kDa}$ complexes were cut out of the gel and the radioactivity determined.

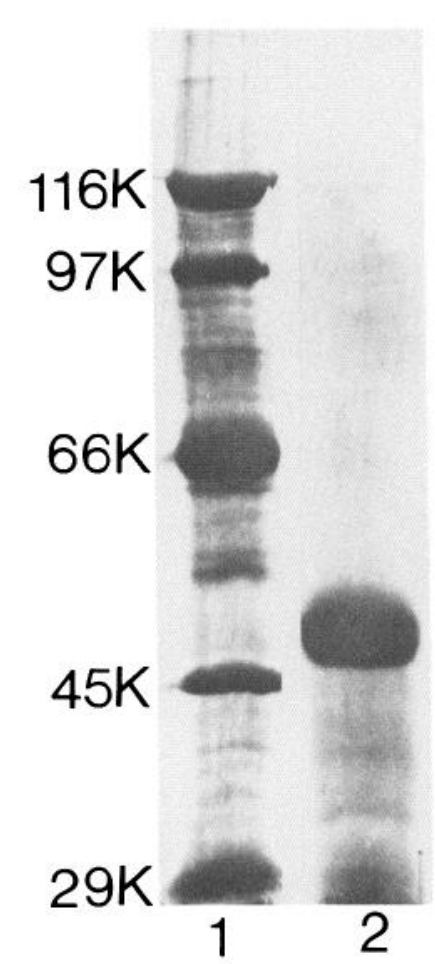

Figure 11. Highly purified preparation of heart inhibitor. The PA inhibitor was purified from heart cell CM by 2 passes over a heparinSepharose column as described in Materials and Methods. Molecularweight markers were loaded in lane 1 (galactosidase, $116 \mathrm{kDa}$; phosphorylase, $97 \mathrm{kDa}$; BSA, $66 \mathrm{kDa}$; ovalbumin, $45 \mathrm{kDa}$; carbonic anhydrase, $29 \mathrm{kDa}$ ) and $5 \mu \mathrm{g}$ of protein eluted from the second heparinSepharose column was loaded into lane 2 . Proteins were separated in a $7 \%$ SDS-polyacrylamide gel in the presence of 4\% 2-mercaptoethanol and silver-stained according to the procedure of Merril et al. (1981).

${ }^{125} \mathrm{I}-\mathrm{UK}$ was taken as a measure of their ability to compete for the inhibitor. Non-serine proteases (thermolysin and aminopeptidase $\mathrm{M}$ ) did not block the formation of either complex, whereas the serine proteases urokinase, trypsin, chymotrypsin, plasmin, and thrombin were about equally effective on blocking the formation of the $68 \mathrm{kDa}$ complex. Formation of the $80 \mathrm{kDa}$ complex was blocked by preincubation with UK, trypsin, chymotrypsin, and plasmin but not by thrombin.

\section{Comparison of the heart inhibitor with other inhibitors of serine proteases}

A number of inhibitors have been described that form stable bonds with various serine proteases (Chandra and Bang, 1977; Owen, 1975; Johnson and Travis, 1976; Baker et al., 1980; Loskutoff et al., 1983; Guenther et al., 1985; Parker and Tollenfsen, 1985). The properties of the heart inhibitor described in the present studies including its molecular weight and ability to bind to heparin-Sepharose are most similar to the protease inhibitor, protease nexin (Baker et al., 1980). To compare the properties of the heart inhibitor in the present study with protease nexin, the binding of the heart inhibitor (eluted from a heparin affinity column with $0.7 \mathrm{M} \mathrm{NaCl}$ ) to octyl-Sepharose was investigated. When protease nexin is loaded on octyl-Sepharose in $1.2 \mathrm{M}$ ammonium sulfate it elutes at $0.7 \mathrm{M}$ ammonium sulfate (Scott and Baker, 1983), whereas the heart inhibitor under investigation in the present study does not elute from octylSepharose at any ammonium sulfate concentration and is eluted 


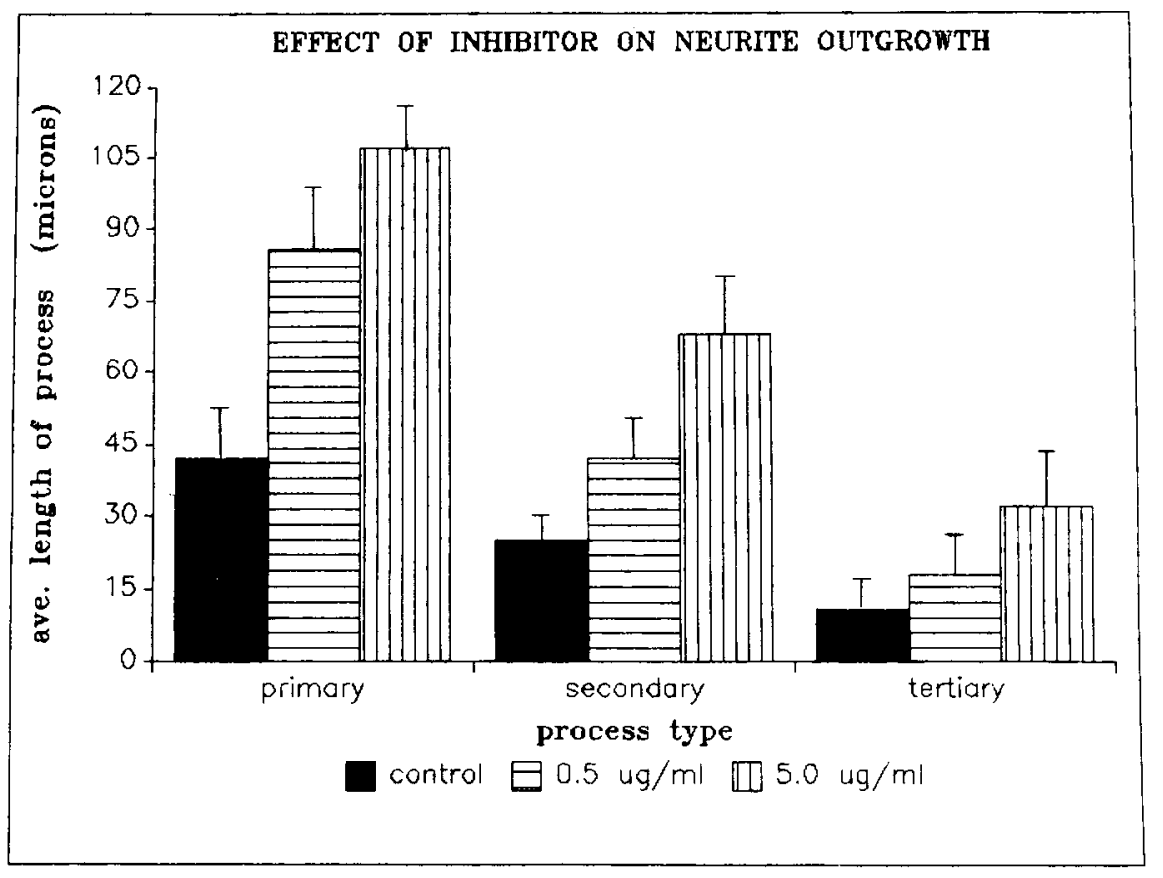

Figure 12. Effect of the heart inhibitor on neurite outgrowth. Sympathetic neurons were plated in the absence or presence of $0.5 \mu \mathrm{g} / \mathrm{ml}$ (目) or $5.0 \mu \mathrm{g} / \mathrm{ml}$ (II) of a highly purified preparation of the heart inhibitor (see Fig. 11 and Materials and Methods) for $18 \mathrm{hr}$. Neurons were then fixed in PBS containing 2\% glutaraldehyde and morphometric data obtained as described in Materials and Methods. Primary processes are those neurites that are directly connected to the cell body, whereds secondary and tertiary processes are defined as neurites that branch from primary and secondary neurites, respectively. Data represent means \pm SEM of 50-200 neurite lengths (for each process type and experimental condition) taken from 18 dishes of neurons. only in the presence of high concentrations of detergent (Fig. $10)$. Even on a less hydrophobic column such as pentyl-Sepharose, detergent $(0.5-1.0 \%$ Triton $X-100)$ was required to remove the heart inhibitor (not shown). These experiments indicate that although many of the properties of the heart inhibitor are similar to protease nexin, the inhibitor appears to be a much more hydrophobic protein.

\section{Effect of the inhibitor on neurite outgrowth}

The inhibitor present in heart cell CM was purified by 2 passes over a heparin-Sepharose column (see Materials and Methods). The purity of the protein eluted from the second column was $>95 \%$ based on SDS gel electrophoresis (Fig. 11). Its molecular weight of $50 \mathrm{kDa}$ agrees well with the molecular weight obtained by probing blotted proteins with ${ }^{125} \mathrm{I}-\mathrm{UK}$ (Fig. 2). The $50 \mathrm{kDa}$ protein forms a $68 \mathrm{kDa}$ complex with $\mathrm{UK}$ but does not form a complex with DFP-treated UK (not shown). A 2- to 3-fold increase in neurite outgrowth occurred when sympathetic neurons were grown in the presence of the highly purified inhibitor (Fig. 12). The outgrowth of primary, secondary, and tertiary processes were all increased by the inhibitor in a dose-dependent manner (Fig. 12).

\section{Discussion}

Sympathetic neurons release a UK-like PA from distal processes and/or growth cones (Pittman, 1985a). The present study was undertaken to determine whether growing sympathetic neurons in the presence of heart cells affected the amount of PA released. Initial studies indicated that little or no PA activity was present in cocultures of neurons and heart cells and that this appeared to be due to the presence of a PA inhibitor released by the heart cells. It did not appear that the inhibitor was a component of the fetal calf serum used to establish the cultures of heart cells. This was based on the following: (1) Although fetal calf serum has 3 proteins that form stable complexes with ${ }^{125} \mathrm{I}-\mathrm{UK}$, none of these complexes have a molecular weight of 68 or $80 \mathrm{kDa}$; (2) highly purified cultures of fibroblasts and myocytes were established in the total absence of serum and were grown for 2-3 weeks in serum-free medium with no decrease in the production of the inhibitor; and (3) the sustained release of the inhibitor into the culture medium was dependent on EGF or phorbol ester in the serum-free medium. Biochemical characterization of the heart inhibitor has been carried out as a first step in determining if this protein has a function in neurite outgrowth dynamics and neuron-target cell interactions.

A number of different cell types release inhibitors of serine proteases (Eaton and Baker, 1983; Van Mourik et al., 1984; Guenther et al., 1985). The function of these inhibitors is unknown; however, it has been suggested that they protect cells from serine proteases released under normal and/or pathological conditions. Work from Monard's laboratory has shown that one such inhibitor of serine proteases is released by glioma cells and increases process outgrowth from neuroblastoma cells (Monard et al., 1983; Guenther et al., 1985; Monard, 1985).

\section{Two inhibitors or one?}

In the early phases of this work it appeared that 2 inhibitors were being released by heart cells. One had a $M_{r}$ of approximately $43 \mathrm{kDa}$, was released primarily by myocytes, and formed a $68 \mathrm{kDa}$ complex with ${ }^{125} \mathrm{I}-\mathrm{UK}$. The other inhibitor had a $M_{r}$ of about $50 \mathrm{kDa}$, was released primarily by fibroblasts, and formed an $80 \mathrm{kDa}$ complex with ${ }^{125} \mathrm{I}-\mathrm{UK}$. Further biochemical analysis of these 2 proteins, however, suggested that they may be two forms of the same protein. The protein that formed the $80 \mathrm{kDa}$ complex with ${ }^{125} \mathrm{~T}-\mathrm{UK}$ migrated with an apparent $M_{r}$ of $>2 \times 10^{6} \mathrm{Da}$ in the absence of SDS, whereas following heparinase treatment, it had an apparent $M_{r}$ of about $50 \mathrm{kDa}$ and formed a $68 \mathrm{kDa}$ complex with ${ }^{125} \mathrm{I}-\mathrm{UK}$. The protein that formed the $68 \mathrm{kDa}$ complex with ${ }^{125}$ I-UK formed a small amount of an 80 $\mathrm{kDa}$ complex in the presence of heparin. These 2 observations are most consistent with there being a single inhibitor protein with a $M_{r}$ of approximately $50 \mathrm{kDa}$. During its interaction with ${ }^{125} \mathrm{I}-\mathrm{UK}$, it is likely that a $6-10 \mathrm{kDa}$ piece of the inhibitor is cleaved as one of the steps leading to the extremely stable com- 
plex that is formed between the inhibitor and UK. It has been shown for the serine protease inhibitors antithrombin III, $\alpha-1$ proteinase inhibitor, and protease nexin that a $6-10 \mathrm{kDa}$ piece of the inhibitor is lost during complex formation (Johnson and Travis, 1976; Chandra and Bang, 1977; Scott and Baker, 1983). The $6-10 \mathrm{kDa}$ polypeptide may not be cleaved from the heart inhibitor if the inhibitor is bound to heparin or heparan sulfate proteoglycan. The ability to maintain the $6-10 \mathrm{kDa}$ polypeptide, as well as formation of a stable complex with a serine protease, has not been described for other protease inhibitors, however.

The fact that a small amount of a $43 \mathrm{kDa}$ inhibitor was detected in CM following gel electrophoresis (Fig. 1) would suggest that 2 inhibitors exist. However, it has been shown for protease nexin that electrophoresis in Tris buffer (as was done in the present studies) results in the dissociation of a small amount of the protease-inhibitor complex and a concomitant loss of $6 \mathrm{kDa}$ in the $M_{r}$ of the inhibitor (Scott and Baker, 1983). This could account for the 2 "apparent" inhibitors in Figure 1. If only one inhibitor is present in heart CM, then the inability of thrombin to inhibit the $80 \mathrm{kDa}$ complex formation (Table 2) could be explained by the binding of thrombin to the heparan sulfate proteoglycan in this preparation (it is known that thrombin binds to heparin), which results in a decrease in the free concentration of thrombin available to interact with the inhibitor. It is still possible that 2 different inhibitors are released by heart cells; however, until large-scale purification of the inhibitor is performed, definitive experiments will not be possible.

Inhibitor as a constituent of heart CM and its effect on neurite outgrowth

Heart cell CM is an excellent source of substrate-attached neurite outgrowth factors (Collins, 1978; Dribin and Barrett, 1980; Adler et al., 1981; Coughlin et al., 1981). Neurite-promoting factors in CM from non-neuronal cells have been identified as laminin, heparan sulfate proteoglycan, and a combination of these molecules (Lander et al., 1982, 1985; Coughlin et al., 1986). Because of the apparent high affinity of the heart inhibitor for heparin, it is reasonable to assume that another normal constituent of these substrate-attached neurite outgrowth factors is the inhibitor characterized in the present study. Heart cell CM prepared and exposed to tissue culture dishes essentially as described by Collins (1978) contains a significant amount of the inhibitor (unpublished observations). In addition, a highly purified preparation of the heart inhibitor increases neurite outgrowth from sympathetic neurons (Fig. 12). Therefore, it appears that the heart inhibitor is a normal constituent of substrate-attached neurite outgrowth factors from heart $\mathrm{CM}$ and may participate in and/or modulate the events resulting in enhanced neurite outgrowth.

Although the heart inhibitor binds the neuronal PA and inhibits its activity, it also binds other serine proteases (Table 2). Therefore, its effect on neurite outgrowth may not involve the neuronal PA, but rather another serine protease associated with the neuron.

\section{Significance of the heart inhibitor in nervous system development}

The heart inhibitor increases neurite outgrowth from sympathetic neurons (Fig. 12); therefore, it may have a direct or modulatory role in neurite outgrowth in vivo. In addition, the inhibitor may be involved in neuron-target interactions. Sympathetic neurons release the serine protease PA from grow- ing neurites (Pittman, 1985a), and a normal target tissue of sympathetic neurons (heart cells) releases an inhibitor of PA (present study). The possibility that neuron-target cell interactions may involve protease-inhibitor interactions is particularly intriguing; however, it must be realized that cardiac fibroblasts also release the inhibitor. Therefore, protease-inhibitor interactions would not be expected to be involved in target recognition, but rather in an event such as decreasing local proteolytic activity so that synaptogenesis could occur. In its simplest form, target cell inhibitors could be used to convert a proteolytically active system, which is useful for neurite outgrowth, to a less active system in which synaptogenesis can proceed. Once synapses were formed, it might be expected that retrogradely transported factors from the target cells would instruct the neuron to down-regulate proteolytic activity; however, until this occurred, local control of proteolysis during active synaptogenesis would be performed by target cell inhibitors. The possibility that more complex interactions may be occurring is suggested by recent observations indicating that sympathetic neurons have a surface protein that binds PA (Pittman, 1985b). Therefore, once the growing neurite approached its target, there would be a competition between the heart inhibitor and the neuronal surface protein for the neuronal PA.

\section{References}

Adler, R., M. Manthorpe, S. D. Skaper, and S. Varon (1981) Polyornithine-attached neurite-promoting factors (PNPFs). Culture sources and responsive neurons. Brain Res. 206: 129-144.

Alvarez-Buylla, A., and J. E. Valinsky (1985) Production of plasminogen activator in cultures of superior cervical ganglia and isolated Schwann cells. Proc. Natl. Acad. Sci. USA 82: 3519-3523.

Baker, J. B., D. A. Low, R. L. Simmer, and D. D. Cunningham (1980) Protease-nexin: A cellular component that links thrombin and plasminogen activator and mediates their binding to cells. Cell $21: 37-$ 45.

Bottenstein, J. E., S. D. Skaper, S. S. Varon, and G. H. Sato (1980) Selective survival of neurons from chick embryo sensory ganglionic dissociates utilizing serum-free supplemented medium. Exp. Cell Res. 125: 183-190.

Chandra, S., and N. U. Bang (1977) Analysis of primary and secondary complexes between antithrombin III, thrombin, and factor Xa. In Chemistry and Biology of Thrombin. R. L. Lundblad, J. W. Fenton, II, and K. G. Mann, eds., pp. 421-429, Ann Arbor Science, Ann Arbor, MI.

Collins, F. (1978) Induction of neurite outgrowth by a conditionedmedium factor bound to the culture substratum. Proc. Natl. Acad. Sci. USA 75: 5210-5213.

Coughlin, M. D., E. M. Bloom, and I. B. Black (1981) Characterization of a neuronal growth factor in mouse heart-cell-conditioned medium. Dev. Biol. 82: 56-68.

Coughlin, M. D., A. K. Grover, and C. Y. Jung (1986) Determination of the molecular weight of neuronectin, a conditioned medium-derived, substrate-binding neurite-extension factor: Comparison with laminin using radiation-inactivation analysis. J. Neurosci. 6: 15531559.

Deutsch, D. G., and E. T. Mertz (1970) Plasminogen: Purification from human plasma by affinity chromatography. Science 170: 10951096.

Dribin, L. B., and J. N. Barrett (1980) Conditioned medium enhances neurite outgrowth from rat spinal cord explants. Dev. Biol. 74: 184195.

Eaton, D. L., and J. B. Baker (1983) Evidence that a variety of cultured cells secrete protease nexin and produce a distinct cytoplasmic serine protease-binding factor. J. Cell. Physiol. 117: 175-182.

Goodman, C. S., M. J. Bastiani, C. Q. Doe, S. du Lac, S. L. Helfand, J. Y. Kuwada, and J. B. Thomas (1984) Cell recognition during neuronal development. Science 225: 1271-1279.

Guenther, J., N. Hanspeter, and D. Monard (1985) A glia-derived neurite promoting factor with protease inhibitory activity. EMBO J. 4: 1963-1966. 
Hawrot, E., and P. H. Patterson (1979) Long-term culture of dissociated sympathetic neurons. Methods Enzymol. 58: 574-584.

Johnson, D. H., and J. Travis (1976) Human alpha-1-proteinase inhibitor mechanism of action by limited proteolysis. Biochem. Biophys. Res. Commun. 72: 33-39.

Kalderon, N. (1984) Schwann cell proliferation and localized proteolysis: Expression of plasminogen-activator activity predominates in the proliferating cell populations. Proc. Natl. Acad. Sci. USA 81: $7216-7220$

Kater, S., and P. C. Letourneau (1985) Biology of the nerve growth cone. J. Neurosci. Res. 13: 1-335.

Krystosek, A., and N. W. Seeds (1981a) Plasminogen activator secretion by granule neurons in cultures of developing cerebellum. Proc. Natl. Acad. Sci. USA 78: 7810-7814.

Krystosek, A., and N. W. Seeds (1981b) Plasminogen activator release at the neuronal growth cone. Science 213: 1532-1534.

Krystosek, A., and N. W. Seeds (1984) Peripheral neurons and Schwann cells secrete plasminogen activator. J. Cell Biol. 98: 773-776.

Laemmli, U. K. (1970) Cleavage of structural proteins during the assembly of the head of bacteriophage T4. Nature 227:680-681.

Lander, A. D., D. K. Fuji, D. Gospodarowicz, and L. F. Reichardt (1982) Characterization of a factor that promotes neurite outgrowth: Evidence linking activity to a heparan sulfate proteoglycan. I. Cell Biol. 94: 574-585.

Lander, A. D., D. K. Fuji, and L. F. Reichardt (1985) Purification of a factor that promotes neurite outgrowth: Isolation of laminin and associated molecules. J. Cell Biol. 101: 898-913.

Letourneau, P. C. (1983) Axonal growth and guidance. Trends Neurosci. 6: 451-455.

Loskutoff, D. J., J. A. van Mourik, L. A. Erickson, and D. Lawrence (1983) Detection of an unusually stable fibrinolytic inhibitor produced by bovine endothelial cells. Proc. Natl. Acad. Sci. USA 80: 2956-2960.

Merril, C. R., D. Goldman, S. A. Sedman, and M. H. Ebert (1981) Ultrasensitive stain for proteins in polyacrylamide gels shows regional variation in cerebrospinal fluid proteins. Science 211: 1437-1438.

Mohamed, S. N. W., R. Homes, and C. R. Hartzell (1983) A serumfree chemically-defined medium for function and growth of primary neonatal rat heart cell cultures. In Vitro 19: 471-478.

Monard, D. (1985) Neuronal cell behavior: Modulation by protease inhibitors derived from non-neuronal cells. Cell Biol. Int. Rep. 9: 297-305.

Monard, D., E. Niday, A. Limat, and F. Solomon (1983) Inhibition of protease activity can lead to neurite extension in neuroblastoma cells. In Progress in Brain Research, Vol. 58: Molecular and Cellular Interactions Underlying Higher Brain Function, J. P. Changeux, J. Glowinski, M. Imbert, and F. E. Bloom, eds., pp. 359-364, Elsevier, New York.

Moonen, G., M. P. Grau-Wagemans, and I. Selak (1982) Plasminogen activator-plasmin system and neuronal migration. Nature 298: 753755.

Owen, W. G. (1975) Evidence for the formation of an ester bond between thrombin and heparin cofactor. Biochim. Biophys. Acta 405: 380-387.

Parker, K. A., and D. M. Tollenfsen (1985) The protease specificity of heparin cofactor II. J. Biol. Chem. 260: 3501-3505.

Pittman, R. N. (1984) Neuron-target cell interactions may involve protease-inhibitor interactions. Soc. Neurosci. Abstr. 10: 662 .

Pittman, R. N. (1985a) Release of plasminogen activator and a calcium-dependent metalloprotease from cultured sympathetic and sensory neurons. Dev. Biol. 110: 91-101.

Pittman, R. N. (1985b) Characterization of a neuronal protein that binds plasminogen activator. Soc. Neurosci. Abstr. 11: 760.

Scott, R. W., and J. B. Baker (1983) Purification of human protease nexin. J. Biol. Chem. 258: 10439-10444.

Soreq, H., and R. Miskin (1983) Plasminogen activator in the developing rat cerebellum: Biosynthesis and localization in granular neurons. Brain Res. 313: 149-158.

Tosney, K. W., and L. T. Landmesser (1985) Development of the major pathways for neurite outgrowth in the chick hindlimb. Dev. Biol. 109: 193-214.

Unkeless, J. C., A. Tobia, L. Ossowski, J. P. Quigley, D. B. Rifkin, and E. Reich (1973) An enzymatic function associated with transformation of fibroblasts by oncogenic viruses. I. Chick embryo fibroblast cultures transformed by avian RNA tumor viruses. J. Exp. Med. 137: 85-111.

Van Mourik, J. A., D. A. Lawrence, and D. J. Loskutoff (1984) Purification of an inhibitor of plasminogen activator (antiactivator) synthesized by endothelial cells. J. Biol. Chem. 259: 14914-14921.

Wolinsky, E., S. C. Landis, and P. H. Patterson (1985) Expression of noradrenergic and cholinergic traits by sympathetic neurons cultured without serum. J. Neurosci. 5: 1497-1508.

Wun, T. C., L. Ossowski, and E. Reich (1982) A proenzyme form of human urokinase. J. Biol. Chem. 257: 7262-7268.

Yang, V. C., R. J. Linhardt, H. Bernstein, C. L. Cooney, and R. Langer (1985) Purification and characterization of heparinase from flavobacterium heparinum. J. Biol. Chem. 260: 1849-1857. 